\title{
On Transformation of Idea of China's Fiscal and Tax Laws
}

\author{
Zhongjian Liu \\ School of Law, Shandong University of Finance and Economics, Ji'nan, 250014, China
}

\begin{abstract}
Keywords: Fiscal and tax law. Economic law. Fiscal and tax idea. Transformation
\end{abstract}
\begin{abstract}
Rapid economic development and establishment of market economy put forward higher requirements for reformation of China's fiscal and tax laws. In recent years, China's fiscal and tax laws have improved continuously. The idea of fiscal and tax laws also continuously develop in the reformation. Compared with other economic law sectors, fiscal and tax laws involve the provisions of citizens' property right. How to better reform fiscal and tax laws and transform the idea of fiscal and tax laws need to be solved in this stage. This paper simply analyzes China's fiscal and tax laws, the idea transformation history and the realistic foundation and proposes some suggestions to promote transformation of fiscal and tax laws, as well as the idea.
\end{abstract}

\section{Overview of fiscal \& tax law and the idea}

Fiscal and tax law is a general name of fiscal law and tax law. Strictly speaking, tax law is a constituent part of fiscal law, but due to the particularity of tax, the academic circle usually parallels fiscal law and tax law and calls them fiscal and tax law generally. The idea of fiscal and tax law refers to cognition of the essence and law of fiscal and tax law. To gain highest rational cognition of the essence of fiscal and tax law, it is necessary to study fiscal and tax law and strive to achieve transformation of the idea of fiscal and tax law. The following points should be focused on during research of the idea of fiscal and tax law. Firstly, the idea of fiscal and tax law is not equal to the concept, awareness and principle of fiscal and tax law. The idea of fiscal and tax law is the highest cognition of the essence of fiscal and tax law. Secondly, except ontology significance, the idea of fiscal and tax law also has epistemology significance and methodology significance. The idea of fiscal and tax law reflects comprehensive mastery of the essence $f$ and law of fiscal and tax law. The idea of fiscal and tax law is the highest expression of guiding ideology of fiscal and tax law.

The idea of fiscal and tax law comes from the practice of fiscal and tax law and is the summary of long-term successful practical experience. Meanwhile, in accordance with Marxism-related theories, the idea of fiscal and tax law will certainly have strong guiding function for practice of fiscal and tax law. The improvement of the idea of fiscal and tax law can perfect China's economic law system and effectively construct benign legal environment so as to promote progress of social civilization.

\section{Fiscal and tax law and idea transformation history}

Chinese and foreign scholars generally accept a viewpoint: the idea of fiscal and tax law mainly includes three aspects: social justice, welfare and democracy. In the meantime, in line with relevant historical materials and researches, in the period with different economic development levels, the development and effects of the idea of fiscal and tax law are different. In particular, during explanation of the three aspects of the idea of fiscal and tax law, the emphases are also different and reflected through different fiscal and tax laws. The idea of fiscal and tax laws with different emphases play a guiding role in prediction, standardization, guidance and education.

\section{Idea of fiscal and tax law in the early period of the establishment of New China}

In the early period of the establishment of New China, based on practical national conditions, China implemented planned economic system in order to rescue China's economy at the edge of collapse. In this period, equal distribution management system was mainly carried out. Fiscal and tax law is highly-concentrated equalitarianism principle. Local fiscal power was subject to the central government. The central government conducted income and expenditure statistics nationwide. The 
whole country only had one-class finance. Firstly, the main source of fiscal revenue was high profit of state-owned economic units. Secondly, distribution was carried out in a unified way according to national fiscal budget. The main source of national fiscal revenue was agricultural tax revenue. On the one hand, the state adopted the measure of production increase without tax increase in order to mobilize peasants' enthusiasm and lighten their burden. On the other hand, in order to promote industrial development, the state implemented the policy of promotion of industry with agriculture. Most values created by agriculture were transferred to industry. Thus, actual burden added to peasants was actually greater than the burden of agricultural tax.

\section{Idea of fiscal and tax law under reform and opening-up policy}

When economic development reached certain level, planned economic system had a strong impact on further improving economic level. So, China adopted the reform and opening-up policy. With the establishment and development of socialist market economy system, China's economic construction has gained certain achievements. Economic construction included construction of economic law. The function of tax law in market economy cannot be replaced. In 1990s, construction of China's tax law further enhanced. Related tax laws and the issuance of new tax categories perfected China's tax law system. New tax laws reflect basic value orientation of the idea of fiscal and tax law - " giving priority to efficiency and considering equity simultaneously" after the reform and opening-up. Under the guidance of such idea, China's economic level also develops and resource allocation optimizes continuously. But, the result of such idea is that social economic development efficiency is dominated and equity is just considered. Finally, income gap among individuals and groups are caused. Such idea of fiscal and tax law deviates from justice and equity in terms of the contents.

\section{Idea of fiscal and tax law in new times}

Development of market economy will inevitably lead to the expansion of the gap between the rich and the poor. Especially in recent years, increasingly extensive gap between the rich and the poor and livelihood issues exposed become the focus of the society. Narrowing the gap between the rich and the poor through social wealth redistribution function on the basis of fiscal and tax law and realization of equity idea of fiscal and tax law should become the main theme of the times. Thus, the fourth generation of leaders collectively put forward "scientific development perspective" aiming to guarantee every citizen to enjoy the results of national economic development. The new leaders represented by the general secretary Xi Jinping propose the idea of great "China dream" . These provide guiding ideology for transforming China’s fiscal and tax law under new situations.

\section{Realistic basis of transformation of fiscal \& tax law and the idea}

\section{Objective needs of China's democratic construction}

Through the process of western countries realizing constitutionalism, we know constitutionalism develops with the development of "democratic finance" and "finance ruled by laws" . In western countries, taxation standard is standardized according to legislation. The government provides services or common products on the basis of taxation. In short, the government can normally exercise rights only after paying taxes in accordance with legal standards and then. It thus can be seen that all tax revenues in western countries must be formulated according to laws and all tax revenues are subject to laws. In addition, revenue expenditure must be implemented according to laws, too. Since the reform and opening-up policy, China's tax revenue mainly has depended on administrative laws and regulations of the government and even other normative documents. Thus, there is lack of relevant public finance idea. The shortcoming resulted from such executive-led fiscal and taxation system is that the right of fiscal tax revenue and revenue-related rights are owned by the government. In this way, taxation system lacking democratic supervision and legal supervision can easily lead to fiscal corruption and many other problems. In the new century, China's fiscal and tax law has gained great achievements in this aspect, but there is still certain gap with foreign advanced fiscal and taxation system. So, transformation of China's fiscal \& tax law and the idea is an objective requirement of China's democratic construction. 


\section{Objective need of socialization of economic law}

At present, civil society and political country mutually influence and penetrate. Social public interest starts to be independent and form independent force. Existing legal system will suffer huge impact of such force. Thus, social relations cannot be adjusted well only through depending on traditional public law or private law. According to related legal knowledge and effects, we can know overuse of private law cannot effectively realize control of monopoly, especially for control of unfair competition. Public law can effectively control market monopoly and unfair competition. However, excessive use of public law will often result in market instability and destruction of competition freedom and justice due to excessive administrative intervention. So, it is urgently necessary to set up a new legal department in combination of the advantages of public law and private law. After the investigation for some time, basic law beneficial to the government to properly intervene economy economic law is generated. Economic law pays close attention to mean economic rights among economic subjects all the time. In line with the general viewpoint of the academic circle, the branches of economic law include fiscal and tax law. As a branch of economic law, fiscal and tax law will be bound to own some attributes and characteristics of economic law. Currently, the research emphasis of China's fiscal and tax law is still the issue of national taxation right. In accordance with existing tax payment policies, overwhelming majority of the groups in the middle and lower classes in the society still bear tax paying obligation unmatched with their economic level. Therefore, China's idea of fiscal and tax law need to continuously reform according to national conditions so as to promote good economic development.

\section{Different explanations of fairness and efficiency in different periods}

It is known according to Marxism-related theories that equity and efficiency is pair of dialectical and unified concepts. Efficiency guarantee provides sufficient material basis for establishment of equity; establishment of equity aims to promote efficiency improvement. Meanwhile, equity and efficiency cannot coexist in a short term. In a short term, pursuit of efficiency will inevitably sacrifice equity; if equity is ensured, the improvement of efficiency will be affected. Thus, under socialism market economy, it is necessary to cautiously select pursuit of equity or efficiency. Seeing from the history, the selection of the two is subject to national conditions. It is required to grasp the main contradictions of economic development according to national conditions. Fiscal and tax law serves as important idea basis of controlling efficiency and equality. It is required to decide selection of equity or efficiency according to practical conditions.

\section{Suggestions on transformation of fiscal \& tax law and the idea}

An efficient approach to achieve transformation of fiscal and tax law is to realize "equalization of basic public services" under the guidance of scientific development perspective. In the Sixth Plenum of the 16th CPC Central Committee, the requirement of perfecting public fiscal system was put forward. Besides, the concrete objective was to achieve equalization of basic public service gradually. The implementation of laws and polices related to fiscal and tax law requires solving economic benefit from policies and laws in combination of national conditions. Meanwhile, economic benefit must directly involve the masses and is mostly concerned by the masses. The requirement put forward by Chinese Communist Party indicates main direction and task of China's legal construction of finance and tax in this stage, i.e. regard transformation of the idea of fiscal and tax law as the emphasis and mainly depend on promoting equalization of basic public service.

As one of major construction objectives of China's fiscal and tax law, the subject of equalization of public service - the government must work in line with the principles of law-based tax administration. Based on existing social average level, public services of the government must be adapted to social and economic development in this stage and show equity principle, and cannot violate the fundamental development principle. Harmonious development of social economy, urban and rural economy and regional economy can be ensured through equalization of basic public services. In this way, joint development of different classes in the society can be realized to make sure 
the gap between the rich and the poor is controlled within certain range so that giant achievements of social and economic development can be shared by the masses averagely.

The basic level of equalization of public service is equalization of basic public service put forward in this paper. Public service field included in equalization of basic public service is wide, mainly involving the service range closely related to the life of the masses such as culture, education, social security and public infrastructure. Thus, the diversity and complexity of basic public service raise new topics for development of fiscal \& tax law and the idea. It is required to drive continuous improvement of transparency and equity of market economic system through transformation of fiscal \& tax law and the idea. Moreover, it is required to restrain increasingly intensive gap between the rich and the poor through transformation of fiscal \& tax law and the idea so that economic development achievements can be shared by different classes and groups evenly. The realization of the series of objectives can promote continuous development of fiscal \& tax law and the idea and lay good foundation for further development of social economy.

The objective to regard the reality of equalization of basic public service as the basic work to evenly share reform and development achievements in the whole society reflects radical change of the idea of China's fiscal law under scientific development perspective. What is especially worth of stating is that such move to specify the objective makes transformation of the idea of ruling by law for China's finance and tax evaluative and operable. This will certainly contribute to implementing legal construction of China's fiscal and tax law. The above also states that transformation and reformation of China's fiscal \& tax law and the idea can be effectively promoted only through regarding equalization of basic public service as economic development foundation and promoting continuous improvement of the level of basic public service.

\section{Conclusions}

In conclusion, as China's economic level develops continuously, it is urgent to transform China's fiscal \& tax law and the idea in order to promote further healthy development of China's economy. During reformation of fiscal and tax law, relevant theoretical researches are essential. Thus, this paper simply proposes some development suggestions through historical development of fiscal and tax law and the importance. To smoothly carry out the reform and opening-up of socialism, make every Chinese realize their "China dream" and achieve the objective of legalization of China's finance and radical change of the idea of China's fiscal law, it is required to regard scientific development perspective as basic guiding ideology and take equalization of basic public service as the objective and important work. Only in this way, construction of China's fiscal and tax law can advance stably; unstable situation caused by national wealth inequality can be changed so as to lay solid foundation for really realizing a country under the rule of law and public finance.

\section{References}

[1] Jin Yi: On transformation of idea of China's fiscal and tax law - centered on equally sharing reform and development achievements, Journal of Heilongjiang Administrative Cadre Institute of Politics and Law, 2010(12)

[2] Wen Chenggong: Thought triggered by Item 11 of Article 2 of Law on personal income tax from realistic and ideal perspective of authorized legislation in revenue, Legal System and Society, 2013(03)

[3] Wu Taixuan: On equal sharing of public investment - thoughts based on path of fiscal and tax law, Taxation and Economy, 2008(06)

[4] Wang Ping: Fiscal and tax reform: to match financial resources with authority of office, The National People's Congress of PRC, 2009(19) 
[5] Gao Peiyong: Comment of new round of tax reform: content, course and prospect, Finance \& Trade Economics, 2009(02)

[6] Zhou Linbin: Sun Linling, Reform and innovation of China's economic law - from perspective of institutional change, Journal of Political Science and Law, 2010(05)

[7] Luo Jiang: Discussion on value comparison of economic law and civil \& commercial law, Legal System and Society, 2010(26) 